EMBRYARIDDLE
Aeronautical University

SCHOLARLY COMMONS
International Journal of Aviation, Aeronautics, and Aerospace

\title{
Book Review: Angle of Attack: Air France 447 and the Future of Aviation Safety
}

Orin L. Godsey

Embry-Riddle Aeronautical University - Worldwide, godseyo@erau.edu

Follow this and additional works at: https://commons.erau.edu/ijaaa

Part of the Other Education Commons

\section{Scholarly Commons Citation}

Godsey, O. L. (2017). Book Review: Angle of Attack: Air France 447 and the Future of Aviation Safety. International Journal of Aviation, Aeronautics, and Aerospace, 4(4). https://doi.org/10.15394/ ijaaa.2017.1195

This Book Review is brought to you for free and open access by the Journals at Scholarly Commons. It has been accepted for inclusion in International Journal of Aviation, Aeronautics, and Aerospace by an authorized administrator of Scholarly Commons. For more information, please contact commons@erau.edu. 


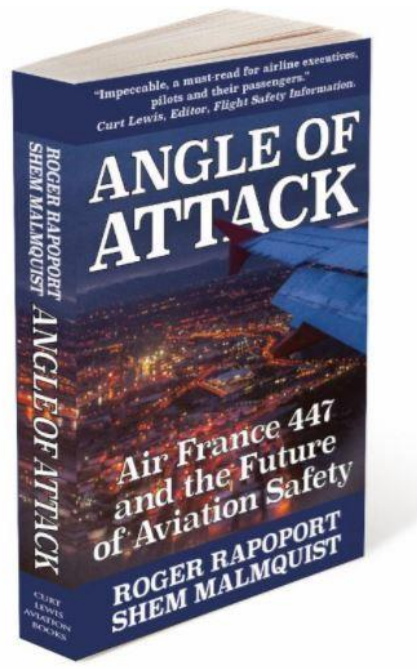

Book: Angle of Attack: Air France 447 and the Future of Aviation Safety

Authors: Roger Rapoport \& Shem Malmquist

Publisher: Lexographic

Year: 2017

Book Price: $\$ 18.95$

eBook Price: NA

Length: 260 pages

Read Time: 4 hours

Read Rating: 5 - Very Easy

Book Rating: 5 - Excellent

The book does an outstanding job of outlining the history of the accident and highlighting the problems associated with and that were contributing factors to the crash of Air France Flt 447. The two authors have a wealth of aviation-related experience. However, an uninformed individual reading the book might not be able to put everything together to realize the driving factors behind the decisions that were made that caused this accident. The one area that is not clearly stated in the book is that the force behind the business decisions that were contributing causes are money/profits, airlines operate on a calculated risk bases, probabilities. Aircraft configuration/equipment and flight crew training are centered upon the airworthiness authority requirement standards which are considered the minimum required. Airlines normally just meet the minimum standards. System safety analysis could be used in more detail to eliminate some of these problems from the design/manufacture to the training of the operators.

The causes of this accident could be grouped into five main areas that were highlighted within the book as contributing factors to the accident: 1) regulatory problems; 2) manufacturing shortcomings; 3) Air France shortcomings; 4) pilot experience/training problems; and 5) search and rescue problems (not involved in the cause of the accident).

It is apparent from the information provided that this accident could have been prevented from an operational standpoint. Air France could have taken near-term actions from the perspective of flight crew training, installing self-contained attitude indicators/angle of attack indicators and by communicating to Air France flight crew members previous similar Air France problems associated with pitot icing and actions to take in case of pitot icing that caused this crash. Knowledge is power. The regulatory airworthiness authorities had earlier recognized a problem with the Thales pitot system and could have taken actions to mandate pitot tube changes as a priority item instead of allowing airlines to make the changes on an as-required basis. The two above actions could have reduced the potential of this accident happening at a modest expense.

Air France was remiss from the standpoint of pilot pairings. Flight hours themselves do not necessarily denote experience, in today's world of automation, a pilot can accumulate thousands of flight hours but still not be experienced from a hands-on flying aspect. Air France should not pair two first officers with one Captain; the different pairing would provide a higher degree of safety. From a human factors standpoint, one cannot expect a Captain to be in a rest period/sleep and suddenly be called into the cockpit to resolve a severe out-of-control situation. The Captain was placed into a perfect human factors dilemma of loss of situational awareness 
where he did not have sufficient time or cues to understand all that had happened to the aircraft or what was occurring to cause the problem. The visual cues were not available to provide this information in a timely manner because of the lack of instrumentation that could have been solved with the inclusion of a self-contained attitude indicator and angle of attack indicator. These two devices would have provided an experienced, trained pilot with the visual cues needed to recognize that the aircraft was in a stall condition and actions required for recovery.

Another area that is very important and must be evaluated is flight crew training. Many pilots entering the industry have minimal experience in partial panel flying or angle of attack interpretation in relation to flight and stalls. In this accident scenario, two of the pilots had limited experience associated with angle of attack flying and partial panel flying. Pilots must be trained on the value of understanding angle of attack of an aircraft in relationship to stalls and the value of flying angle of attack only. A pilot must be trained and knowledgeable to recognize stall conditions and stall recovery procedures.

Questions that apply to this accident that should be addressed: 1) Is flight crew training sufficient in today environment; 2) are aircraft becoming too automated, are they smarter than the flight crew that operate them; 3) should airworthiness authorities be more proactive in setting minimum standards; 4) are airlines shortcutting safety to increase profitability (items 3 and 4 are interrelated)? The situation that happened in his accident was pre-ordained, it was not a case of "if" but "when." Blame can be assessed across a broad spectrum of organizations, from the airworthiness authorities, manufacturers, airlines and flight crew training. One fact that is a driver and must be remembered is that an airline is a business and the goal of every business is profitability. Decisions are based upon profit making. This book is an excellent rundown on the accident; I would recommend that all aviation professionals read this book.

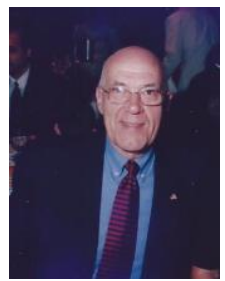

Orin Godsey, Brig Gen, USAF Retired, is currently Associate Program Chair for the Bachelor Science In Aeronautics Degree, he is an Associate Professor at Embry-Riddle Aeronautical University (Worldwide Campus). His military career included extensive flying and instructing in the KC-135 and FB-111 aircraft. He holds a Masters in Business Administration (MBA) (Rensselaer Polytechnic Institute) and a Masters of Aeronautical Science (Embry-Riddle Aeronautical University). 